\title{
Taxol-resistant Epithelial Ovarian Tumors Are Associated with Altered Expression of Specific $\beta$-Tubulin Isotypes
}

\author{
Maria Kavallaris, ${ }^{\star}$ Dennis Y.-S. Kuo, ${ }^{\ddagger}$ Catherine A. Burkhart, ${ }^{\star}$ Donna Lee Regl, ${ }^{\star}$ Murray D. Norris, ${ }^{\S}$ Michelle Haber, ${ }^{\S}$ \\ and Susan Band Horwitz* \\ *Department of Molecular Pharmacology and ${ }^{\ddagger}$ Department of Obstetrics and Gynecology, Division of Gynecological Oncology, Albert \\ Einstein College of Medicine and Montefiore Medical Center, Bronx, New York 10461; and ${ }^{\S}$ Children's Cancer Research Institute, Sydney \\ Children's Hospital, Randwick, New South Wales, 2031, Australia
}

\begin{abstract}
The treatment of advanced ovarian cancer with taxol is hindered by the development of drug resistance. The cellular target for taxol is the microtubule that is stabilized by the drug. Taxol preferentially binds to the $\beta$ subunit of tubulin of which there are six distinct isotypes in mammalian cells. We have used highly specific oligonucleotides and polymerase chain reaction to analyze expression of all six $\beta$-tubulin genes. Human lung cancer cells (A549) were selected in 12 and $24 \mathrm{nM}$ taxol resulting in cell lines that were 9- and 17-fold resistant, respectively. These cells displayed an altered ratio of classes I, II, III, and IVa $\beta$-tubulin isotypes. Ovarian tumors, seven untreated primary and four taxolresistant tumor-bearing ascites, displayed significant increases $(P<0.005)$ in classes I (3.6-fold), III (4.4-fold), and IVa (7.6-fold) isotypes in the taxol-resistant samples as compared with untreated primary ovarian tumors. The increased expression appears to be related to the resistance phenotype, as the basal levels of the class III and IVa isotypes in the untreated tumors were extremely low. This is the first report of altered expression of specific $\beta$-tubulin genes in taxol-resistant ovarian tumors and we propose that the latter may play a role in clinical resistance to taxol. ( $J$. Clin. Invest. 1997. 100:1282-1293.) Key words: drug resistance $\cdot$ carcinoma $\cdot$ microtubules $\cdot$ lung $\cdot$ polymerase chain reaction
\end{abstract}

\section{Introduction}

Ovarian cancer is the leading cause of death from gynecological malignancies in the United States (1). The majority of patients present with advanced stage disease, and after cytoreductive surgery, chemotherapy remains the most effective treatment. Despite significant initial response rates for advanced ovarian carcinoma using platinum-based combination chemotherapy, many patients relapse and $<15 \%$ will be longterm survivors (2). Overall, chemotherapy is relatively ineffec-

Address correspondence to Susan Band Horwitz, Department of Molecular Pharmacology, Albert Einstein College of Medicine, 1300 Morris Park Ave., Bronx, NY 10461. Phone: 718-430-2163; FAX: 718-4308922; E-mail: shorwitz@aecom.yu.edu

Received for publication 28 January 1997 and accepted in revised form 16 June 1997.

J. Clin. Invest.

(C) The American Society for Clinical Investigation, Inc. 0021-9738/97/09/1282/12 \$2.00

Volume 100, Number 5, September 1997, 1282-1293

http://www.jci.org tive due to the emergence of a broad cross-resistance pattern that is either intrinsic to the tumor or acquired after chemotherapy (3). An important clinical advance has been the encouraging use of taxol in combination with cisplatin in first-line therapy in advanced stage ovarian carcinoma (4). Taxol has also proven effective in the treatment of other drug refractory human cancers such as breast (5) and non-small cell lung cancer (6).

Despite the success of taxol as an antitumor agent, clinical drug resistance poses a major impediment to the successful use of this agent in the treatment of cancer. Due to the hydrophobic nature of taxol, resistance to this drug has been associated with the induction of the multidrug resistance (MDR) $)^{1}$ phenotype and overproduction of P-glycoprotein (7). Taxol was first isolated from the bark of the western yew, Taxus brevifolia, and was shown to be cytotoxic to a wide range of murine neoplasms (8). It is an antimitotic agent that binds to microtubules, thereby stabilizing them against depolymerization and inhibiting cell replication by disrupting normal mitotic spindle formation (9). Tubulin is a heterodimer that consists of $\alpha$ - and $\beta$-tubulin subunits that constitute the microtubule. The genes that encode tubulin have been highly conserved throughout evolution, and even within species multiple $\alpha$ - and $\beta$-tubulin genes encode distinct tubulin gene products. Direct photoaffinity labeling has demonstrated that taxol binds preferentially to the $\beta$ subunit of the microtubule (10). To date, mutations or changes in the expression of $\beta$-tubulin in human tumor cells have been poorly defined. One of the difficulties encountered in the study of tubulin in human taxol-resistant cells is the presence of multiple tubulin isotypes that are encoded by a large multigene family consisting of both functional and nonfunctional genes $(11,12)$. The greatest diversity between the $\beta$-tubulin isotypes occurs in the carboxy-terminal variable region sequence and to a lesser extent in the amino-terminal variable domain. Sullivan and Cleveland (13) used the carboxyterminal region of individual isotypes to devise a classification system to distinguish the isotypes in vertebrates, since this region is conserved across species. In humans, six $\beta$-tubulin isotypes have been identified which display a distinct pattern of tissue expression. Their classification is as follows (Roman numerals represent the tubulin protein class, while Arabic numerals represent the gene): class I, HM40; class II, H $\beta$ 9; class III, H $\beta 4$; class IVa, H5 $\beta$; class IVb, H $\beta 2$; class VI, H $\beta 1$ (13, 14). In mammalian cells expression is as follows: class I and $\mathrm{IVb}$ isotypes are constitutively expressed; class III and IVa are restricted to brain; class II is found predominantly in brain and at low levels in a broad range of tissues; and class VI is re-

1. Abbreviations used in this paper: MAP, microtubule-associated protein; MDR, multidrug resistance; RT, reverse transcription. 
stricted to hematopoietic tissues. Although the tissue distribution of each isotype has been well characterized for chicken and mouse, limited data are available on $\beta$-tubulin isotype gene expression in normal human tissues (15-17).

Whether differential expression of specific isotype classes can alter the functional characteristics of microtubules and the response of a cell to taxol is not clear. In vitro studies have demonstrated that the $\beta$-tubulin subunit composition can alter the growing and shortening dynamics of microtubules (18), and that low levels of taxol can alter microtubule dynamics $(19,20)$. Furthermore, $\beta$-tubulin class III-depleted microtubules display increased sensitivity to taxol-induced polymerization in vitro, compared with unfractionated tubulin (21). We have previously described a taxol-resistant murine J774.2 cell line with increased expression of the class II $\beta$-tubulin isotype, $M \beta 2$ (22). To examine the effect of taxol on human malignant cell populations, we have selected non-small cell lung cancer cells for low level resistance to taxol and developed specific oligonucleotides for gene expression analysis of the six human $\beta$-tubulin isotypes. Altered gene expression of specific $\beta$-tubulin isotypes was associated with increasing resistance to taxol. To examine tubulin changes associated with clinical resistance to taxol, untreated primary and taxol-resistant ovarian epithelial tumors were examined for alterations in $\beta$-tubulin isotype composition. Significant increases in $\beta$-tubulin gene expression were observed for $\mathrm{HM} 40, \mathrm{H} \beta 4$, and $\mathrm{H} 5 \beta$ isotypes in taxol-resistant tumors, compared with untreated primary tumors. This is the first report of altered expression of specific $\beta$-tubulin genes in taxol-resistant ovarian tumors and indicates that clinical resistance to taxol may be associated with enhanced expression of specific $\beta$-tubulin isotypes.

\section{Methods}

Patient samples. Tissue samples were obtained from patients with primary ovarian carcinoma undergoing surgical staging, and pre- and postmenopausal patients with benign pathologic conditions undergoing hysterectomy at the Weiler Division of the Albert Einstein College of Medicine and Montefiore Medical Center. All material for this project was obtained with the approval of the internal review board at the Montefiore Medical Center. Samples were snap-frozen in liquid nitrogen and stored at $-70^{\circ} \mathrm{C}$. Taxol-resistant tumor cells were obtained by pelleting the cells from tumor-bearing ascites fluid. Briefly, removal of contaminating red blood cells was achieved by diluting the pellet (1:4) in sterile red blood cell lysing solution (160 mM ammonium chloride, $12 \mathrm{mM}$ sodium bicarbonate, $0.1 \mathrm{mM}$ EDTA, $\mathrm{pH}$ 7.3) and incubating at room temperature for $3 \mathrm{~min}$. Tumor cells were then pelleted and the lysis step was repeated. Pelleted tumor cells were then resuspended in RPMI 1640 and cell counts were performed before the isolation of total RNA. Isolated tumor cells were examined under phase-contrast microscopy and viable cells were counted using trypan blue exclusion dye. In addition, all ascites fluid samples were independently examined by a pathologist and found to be representative of tumor cells obtained from the primary tumor. Ovarian tumors were defined as taxol-resistant if they progressed during or recurred within 6 mo of receiving taxol treatment.

Selection of taxol-resistant cell lines. Human lung carcinoma cells, A549, together with their taxol-resistant derivatives, were maintained in RPMI 1640 containing 1\% penicillin-streptomycin (Gibco Laboratories, Grand Island, NY) and 10\% FBS. Human non-small cell lung cancer cells (A549) were selected for resistance to taxol in a stepwise manner essentially as described $(23,24)$. A549 cells were initially exposed to $1.5 \mathrm{nM}$ of taxol (Drug Development Branch, National Cancer Institute, Bethesda, MD) and once normal growth was achieved, cells were maintained at this concentration before the drug dose was increased in multiples of two. A549-T12 and A549-T24 were maintained at a final concentration of 12 and $24 \mathrm{nM}$ taxol, respectively.

Growth inhibition assays. Exponentially growing cells were resuspended in either drug-free medium (A549) or in the presence of $12 \mathrm{nM}$ (A549-T12) or $24 \mathrm{nM}$ (A549-T24) taxol. The resistant cells require taxol to maintain normal cell proliferation. Cells were seeded at a density of $10^{4}$ cells $/ \mathrm{ml}$ (A549) or $3 \times 10^{4}$ cells/ml (A549-T12 and A549-T24) in triplicate 6-well plates and allowed to attach for $24 \mathrm{~h}$, before the addition of the indicated drug concentrations. After a 72-h incubation, cells were trypsinized and counted (counter model ZF0031; Coulter Electronics Inc., Hialeah, FL).

Protein analysis of tubulin. Cells were lysed in ice-cold RIPA buffer $(150 \mathrm{mM} \mathrm{NaCl}, 1 \% \mathrm{NP}-40,0.5 \%$ sodium deoxycholate, $0.1 \%$ SDS, $50 \mathrm{mM}$ Tris, $\mathrm{pH}$ 7.5) containing a cocktail of protease inhibitors (at a final concentration of $1 \mu \mathrm{g} / \mathrm{ml}$ leupeptin, antipain, chymostatin, and pepstatin A) for $30 \mathrm{~min}$ at $4^{\circ} \mathrm{C}$. After lysis, samples were centrifuged at $4^{\circ} \mathrm{C}$ for $10 \mathrm{~min}$ at $10,000 \mathrm{~g}$. The supernatant was collected and the protein content of the cell lysate was quantitated using the Bio-Rad protein assay reagent (Bio-Rad, Hercules, CA). Total cellular proteins $(10 \mu \mathrm{g})$ were resolved using $12 \%$ SDS-PAGE and transferred to nitrocellulose membranes by standard methods (25). Nitrocellulose blots were probed with mAb to either $\alpha$-tubulin $(1: 1,000$, T-9026; Sigma Chemical Co., St. Louis, MO) or $\beta$-tubulin $(1: 1,000$, T-4026; Sigma Chemical Co.) before exposure of the membrane to anti-mouse horseradish peroxidase-linked IgG antibody (Transduction Laboratories, Lexington, $\mathrm{KY}$ ) and developed using the ECL chemiluminescence procedure (Amersham, Arlington Heights, IL). Blots were then exposed to Hyperfilm-ECL film (Amersham). The relative amount of each protein was determined by densitometry. Equal loadings and efficient transfer of proteins were confirmed by staining the membrane with ponceau $\mathrm{S}$ red before immunodetection.

Partial DNA sequencing of hematopoietic-specific $\beta$-tubulin isotype, $H \beta 1$. Since no nucleotide sequence for the human class VI isotype was available, a DNA clone (pHindIII subclone in pUC8) of the gene corresponding to the class VI isotype, $\mathrm{H} \beta 1$, was kindly provided by Dr. N. Cowan and Dr. S. Lewis. Sequencing of plasmid DNA was performed using the fmol DNA sequencing System (Promega, Madison, WI). Sequence analysis of the DNA clone was obtained with a degenerate consensus antisense primer (5'-GTGCACGATYTCNCKCAT$3^{\prime}$ ) designed using a conserved region of the $\beta$-tubulin gene family.

Reverse transcription-PCR (RT-PCR) analysis of $\beta$-tubulin isotypes. Total RNA was isolated from normal ovary and ovarian tumor samples as described by Chomczynski and Sacchi (26) with minor modifications (27). For cell lines and tumor-bearing ascites samples, total RNA was isolated using TRI Reagent ${ }^{\mathrm{TM}}$ (28) (Molecular Research Center, Inc., Cincinnati, OH). Contaminating genomic DNA was removed from total RNA by treating samples extensively with RNase-free DNase (Boehringer Mannheim, Indianapolis, IN).

Reverse transcription of total cytoplasmic RNA $(1 \mu \mathrm{g})$ was performed as described (29). To confirm that all contaminating DNA had been removed, each RNA sample was subjected to a mock reverse transcription by omitting the reverse transcriptase from the reaction mix. A PCR mix containing $50 \mathrm{ng}$ of cDNA, $1 \mathrm{U}$ of AmpliTaq Gold $^{\mathrm{TM}}$ DNA Polymerase (Perkin Elmer Cetus, Foster City, CA), dNTPs (each at a final concentration of $200 \mu \mathrm{M}$ ), primers (each at a final concentration of $1 \mu \mathrm{M}$ ) in a final volume of $25 \mu \mathrm{l}$ was subjected to PCR for 35 cycles ( 30 cycles for HM40) in a programmable thermocycler. PCR was performed over a range of cycle numbers to ensure that products were amplified in the linear range of the reaction for both the test and control genes. After an initial denaturation of $10 \mathrm{~min}$ at $94^{\circ} \mathrm{C}$, each cycle consisted of $30 \mathrm{~s}$ at $94^{\circ} \mathrm{C}, 30 \mathrm{~s}$ at $55^{\circ} \mathrm{C}$, and $90 \mathrm{~s}$ at $72^{\circ} \mathrm{C}$. Complete removal of contaminating DNA was confirmed by performing a PCR amplification on the relevant samples using the glyceraldehyde-3'-phosphate dehydrogenase gene which spanned an intronic sequence as previously described (30). The genespecific PCR primers are listed in Table I and were designed for $\beta$-tubulin isotypes $\mathrm{HM} 40, \mathrm{H} \beta 4, \mathrm{H} 5 \beta$, and $\mathrm{H} \beta 2$ from sequence information 


\begin{tabular}{|c|c|c|c|c|c|}
\hline \multirow[b]{2}{*}{ Isotype class } & \multirow[b]{2}{*}{ Gene } & \multirow[b]{2}{*}{ Site of forward primer } & \multicolumn{2}{|c|}{ Nucleotide sequence } & \multirow[b]{2}{*}{ Product size } \\
\hline & & & Forward & Reverse & \\
\hline & & & & & $b p$ \\
\hline I & HM40 & $5^{\prime} \mathrm{UTR}$ & 5'ACCTCGCTGCTCCAGCCTCT3' & 5'CCGGCCTGGATGTGCACGAT3' & 154 \\
\hline II & H $\beta 9$ & Coding region & 5'CGCATCTCCGAGCAGTTCAC3' & 5'TCGCCCTCCTCCTCCTCGA3' & 208 \\
\hline III & $\mathrm{H} \beta 4$ & 3'UTR & 5'CTGCTCGCAGCTGGAGTGAG3' & 5'CATAAATACTGCAGGAGGGC3' & 141 \\
\hline IVa & $\mathrm{H} 5 \beta$ & 5'UTR & 5'TCTCCGCCGCATCTTCCACC3' & 5'CCGGCCTGGATGTGCACGAT3' & 114 \\
\hline $\mathrm{IVb}$ & $\mathrm{H} \beta 2$ & $5^{\prime} \mathrm{UTR}$ & 5'GAGCTTGCCAGCCTCGTTCT3' & 5'CCGATCTGGTTGCCGCACTG3' & 215 \\
\hline \multirow[t]{2}{*}{ VI } & $\mathrm{H} \beta 1$ & 5'UTR & 5'ACAGTGTGTTGGCTCACACC3' & 5'CCGATCTGGTTGCCGCACTG3' & 142 \\
\hline & $\beta_{2} \mathrm{M}$ & Coding region & 5'ACCCCCACTGAAAAAGATGA3' & 5'ATCTTCAAACCTCCATGATG3' & 120 \\
\hline
\end{tabular}

available from GenBank. Primer sequences used for $\mathrm{H} \beta 9$ expression have been described previously (31). Sequence data for $\mathrm{H} \beta 1$ were obtained as described in the preceding section. Both target ( $\beta$-tubulin) and control ( $\beta_{2}$-microglobulin) gene sequences were coamplified in the same tube unless otherwise stated. Full-length DNA and cDNA clones of all six human $\beta$-tubulin isotypes were used to confirm the specificity of the primer pairs. DNA clones for HM40, H $\beta 9, \mathrm{H} 5 \beta$, $\mathrm{H} \beta 2$, and $\mathrm{H} \beta 1$ were generously provided by Dr. N. Cowan and Dr. S. Lewis, and the H $\beta 4$ cDNA clone was kindly provided by Dr. D. Cleveland. To confirm the specificity of each primer set, the PCR product for each of the $\beta$-tubulin isotypes amplified from a given $\beta$-tubulin-harboring plasmid was subjected to direct cycle sequencing (fmol DNA Sequencing System; Promega) with the oligonucleotide primers used for amplification. For the determination of $M D R 1$ expression, a competitive PCR reaction with $\beta_{2}$-microglobulin was performed as described previously (29). The expected product size for the MDR 1 primers, based on published sequence data, is $167 \mathrm{bp}$. PCR products $(10 \mu \mathrm{l})$ were resolved using $10 \%$ PAGE and then stained with ethidium bromide, before visualization and Polaroid photography on an ultraviolet transilluminator. Photographic negatives were subjected to densitometry and a ratio for the target gene and the $\beta_{2}$-microglobulin PCR product, for each cDNA sample, was obtained by dividing the densitometric volume of the target gene electrophoretic band by that of the $\beta_{2}$-microglobulin band $(30,32)$. Between three and six independent PCR reactions were performed for each sample and analyzed in this way.

Southern analyses of plasmids. Plasmid DNA (250 ng), each harboring the human $\beta$-tubulin gene encoding an individual isotype, (HM40, H $\beta$, H $\beta 4, \mathrm{H} 5 \beta, \mathrm{H} \beta 2$, or H $\beta 1$ ), was electrophoretically separated in a $0.8 \%$ agarose gel using $1 \times \mathrm{TBE}(90 \mathrm{mM}$ Tris- $\mathrm{HCl} ; 90 \mathrm{mM}$ boric acid; 2 mM EDTA, $\mathrm{pH}$ 8.3) followed by alkaline Southern transfer onto nylon membrane as described previously (33). Isotypespecific oligonucleotide probes for $\mathrm{HM} 40, \mathrm{H} \beta 4, \mathrm{H} 5 \beta$, and $\mathrm{H} \beta 2$ were designed based on sequences obtained from GenBank, or from sequencing DNA clones of $\mathrm{H} \beta 9$ and $\mathrm{H} \beta 1$ (Table II). Blots were hybrid- ized using ExpressHyb solution (Clonetech, Palo Alto, CA) at appropriate temperatures (Table II) for $1 \mathrm{~h}$ with $\gamma^{-32} \mathrm{P}$-end-labeled probes, washed in $2 \times \mathrm{SSC} / 0.05 \%$ SDS for $40 \mathrm{~min}$ at room temperature followed by a wash in $0.1 \times \mathrm{SSC} / 0.1 \%$ SDS for $30 \mathrm{~min}$ at the hybridization temperature. The blots were visualized by exposure to Kodak $\mathrm{X}$-Omat film.

Northern analysis. Total cellular RNA $(30 \mu \mathrm{g})$ was subjected to electrophoresis on $1 \%$ agarose gels containing $1 \times 20 \mathrm{mM}$ morpholinopropanesulfonic acid $/ 5 \mathrm{mM}$ sodium acetate/1 mM EDTA buffer, $\mathrm{pH} 7.0$, and $6 \%$ formaldehyde (34). After electrophoresis, gels were transferred onto nylon membrane using $10 \times$ SSC as the transfer solution. Hybridization and autoradiography were as described for Southern analysis.

Immunofluorescence and digital scanning. A549 and A549-T24 cells were grown to subconfluency on glass coverslips. Cells were rinsed in PBS before extraction for 4 min with $0.5 \%$ Triton X-100 in microtubule stabilizing buffer PEM (100 mM Pipes, pH 6.8; 2 mM EGTA; 2 $\mathrm{mM} \mathrm{MgCl}$ ). PEM-washed cells were then fixed in $3 \%$ formaldehyde for $30 \mathrm{~min}$ at room temperature before rinsing in PEM buffer. Nonspecific binding was blocked by incubating cells with 5\% BSA in PBS for $1 \mathrm{~h}$ at $37^{\circ} \mathrm{C}$. After PBS washing, cells were incubated for $1 \mathrm{~h}$ at $37^{\circ} \mathrm{C}$ with $\mathrm{mAb}$ to $\alpha$-tubulin (Sigma 1:200 dilution; $1 \%$ BSA in PBS) or $\mathrm{mAb}$ to class III $\beta$-tubulin (Sigma 1:50 dilution; $1 \%$ BSA in PBS). PBS-rinsed cells were incubated with Cy3-conjugated anti-mouse IgG (1:1,000; Amersham) for $1 \mathrm{~h}$ before mounting in 30\% glycerol/ PBS containing $1 \mathrm{mg} / \mathrm{ml} \beta$-phenylenediamine (Sigma). Fluorescence was imaged with an Olympus IX70 inverted microscope. Images were digitized with a Photometrics PXL camera and analyzed using Iplab Spectrum software (Signal Analytics Corp., Vienna, VA). Individual cells were traced and the mean fluorescence intensity and area of at least 100 cells for each staining were measured. Immunofluorescence experiments were performed three times and similar results were obtained each time.

Statistical analysis. Differences between samples or groups of samples in terms of their PCR ratios for a given $\beta$-tubulin isotype

Table II. Isotype-specific Oligonucleotide Probes Used for Southern and Northern Hybridization

\begin{tabular}{llccc}
\hline Isotype class & Gene & Site of oligonucleotide & Oligonucleotide sequence & Hybridization temperature $\left({ }^{\circ} \mathrm{C}\right)$ \\
\hline I & HM40 & 5'UTR & 5'-GGAAGGTTGGAATGCGCCCCAGAGGCTGGAGCAGCGAGGT-3' & 65 \\
II & H $\beta 9$ & 5'UTR & 5'-CGCAGACATCGGCCATATTATGGGGATAGACTGAAAGGCT-3' & 55 \\
III & H $\beta 4$ & 3'UTR & 5'-GCCCCGGCCGCCACCTGCCTCTCACTCCAGCTGCGAGCAG-3' & 65 \\
IVa & H5 & 5'UTR & 5'-GAGCTGCGGCGGCGGCGACGGGTGGAAGATGCGGCGGAGA-3' & 65 \\
IVb & H $\beta 2$ & 5'UTR & 5'-TAGTCTCGGAATGGGCTGCCAGAACGAGGCTGGCAAGCTC-3' & 60 \\
VI & H $\beta 1$ & 5'UTR & 5'-CCCAAGTCTGAGATCTTCACGGAATCCTCAGACTCTCAGA-3' & 55
\end{tabular}




\begin{tabular}{|c|c|c|c|c|c|c|}
\hline \multirow[b]{2}{*}{ Cell line } & \multicolumn{6}{|c|}{$\mathrm{ID}_{50}(\mathrm{nM})^{*}$} \\
\hline & Taxol & Taxotere & Vinblastine & Colchicine & Adriamycin & Bleomycin \\
\hline A549 & 2 & 1.75 & 0.775 & 32.5 & 33.3 & 125 \\
\hline A549-T12 & $18(9)^{\S}$ & $7.38(4.2)$ & $1.15(1.5)$ & $33(1)$ & $56.5(1.7)$ & $98.5(0.8)$ \\
\hline A549-T24\| & $34.5(17.3)$ & $17.75(10.1)$ & $1.05(1.4)$ & $43(1.3)$ & $71(2.1)$ & $171(1.4)$ \\
\hline
\end{tabular}

* $\mathrm{ID}_{50}$, drug concentration that inhibits cell division by $50 \%$ after $72 \mathrm{~h}$. ${ }^{\ddagger}$ Cells were maintained in $12 \mathrm{nM}$ taxol during cross-resistance experiments. ${ }$ Cells were maintained in $24 \mathrm{nM}$ taxol during cross-resistance experiments. ${ }^{\S}$ Numbers in parentheses, ratio of $\mathrm{ID}_{50}$ for resistant cell line to that for A549.

gene were determined by Student's $t$ tests using two-sided $P$ values (Statview; Abacus Concepts, Inc., Berkeley, CA).

\section{Results}

Cross-resistance of cell lines. Drug sensitivity of the taxolresistant cell lines to a range of cytotoxic agents was determined using 72-h cytotoxicity assays. A549 cells were highly sensitive to taxol, with an $\mathrm{ID}_{50}$ of $2 \mathrm{nM}$. The A549-T12 and A549-T24 sublines, maintained continuously in the presence of 12 and $24 \mathrm{nM}$ of taxol, respectively, displayed their highest level of resistance to the selecting drug (Table III). The fold resistance was determined by dividing the $\mathrm{ID}_{50}$ of the resistant cells by the $\mathrm{ID}_{50}$ of parental A549 cells. Taxol-selected cells, A549-T12 and A549-T24, were 9- and 17-fold resistant to taxol, respectively. Significant cross-resistance was also observed to another taxane, taxotere, in both A549-T12 (4-fold) and A549-T24 (10-fold). The resistant cell lines demonstrated very little, if any, cross-resistance to adriamycin, bleomycin, or to the antimicrotubule agents vinblastine and colchicine.

Analysis of MDR1 gene expression by RT-PCR. To determine the role, if any, of $\mathrm{P}$-glycoprotein in mediating resistance in A549-T12 and A549-T24 cells, RT-PCR was performed to determine $M D R 1$ gene expression. Detectable expression of $M D R 1$ was not observed in either the parental A549 cells or in the taxol-resistant A549-T12 cells (Fig. 1). In contrast to the P-glycoprotein-positive cell line, SKVLB (kindly provided by Dr. V. Ling), which expresses high levels of $M D R 1$ (27), low levels of $M D R 1$ transcript were detected in A549-T24 cells. These data are consistent with a recent observation that there is no significant difference in $\left[{ }^{3} \mathrm{H}\right]$ taxol accumulation between the parental (A549) and drug-resistant cell lines A549-T12 and A549-T24 (Yang, C.-P.H., and S.B. Horwitz, personal communication).

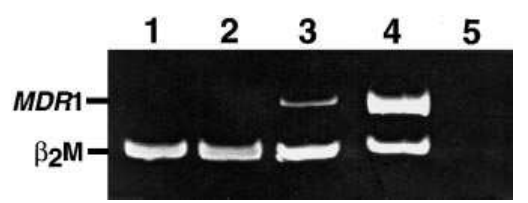

Figure 1. RT-PCR determination of $M D R 1$ gene expression was performed on drug-sensitive A549 (lane 1), taxol-selected A549-

T12 and A549-T24 (lanes 2 and 3), and SKVLB (lane 4), an MDR cell line included as a positive control. Competitive RT-PCR, involving coamplification of $M D R 1(167 \mathrm{bp})$ and control $\beta_{2}$-microglobulin (120-bp) gene sequences, was subjected to 30 cycles and the products were separated on $10 \%$ PAGE followed by ethidium bromide staining. Lane 5, water control.
Analysis of $\alpha$ - and $\beta$-tubulin in taxol-resistant cell lines. Protein levels of $\alpha$ - and $\beta$-tubulin in parental and taxol-resistant cells were determined by immunoblotting of total cell lysates (Fig. 2). No significant change in either $\alpha$ - or $\beta$-tubulin concentration was detected in the taxol-resistant cells compared with the parental cells. These data do not exclude the possibility that individual isotype classes are altered.

Partial sequence of class VI $\beta$-tubulin isotype gene. The distribution of specific $\beta$-tubulin isotypes has been well characterized in both chicken and mouse, however, this has not been the case for human tissues where expression data and tissue distribution of specific isotypes have been determined primarily using human tumor cell lines (15-17). To date, it has been difficult to characterize the gene expression of all six human $\beta$-tubulin isotypes due to the lack of available nucleotide sequence data. The mammalian class VI isotype, which shares the lowest amino acid homology (78\%) to the other isotypes, is restricted in expression to hematopoietic tissues such as platelets, bone marrow, and spleen (17). To generate PCR oligonucleotide primers and gene-specific oligonucleotide probes to the human class VI gene, a H $\beta 1$ DNA clone was partially sequenced (Fig. 3). A degenerate antisense oligonucleotide primer and cycle sequencing was used to obtain data in the 5'UTR region of H $\beta 1$. Sequence was obtained for 106 nucleotides of the 5'UTR and 57 nucleotides coding for the 19 amino acids of exon 1. Confirmation that the sequence was that of $\mathrm{H} \beta 1$ was obtained by identifying the unique amino acid substitution, isoleucine, at position nine $(16,17)$. In the other five isotypes, the ninth amino acid of exon 1 is alanine.

Analysis of $\beta$-tubulin isotype expression in taxol-resistant cell lines. The coding regions of the $\beta$-tubulin genes have highly conserved sequences making the design of isotype-specific primers for RT-PCR within these regions difficult. Previously, we described a strategy for designing oligonucleotide-specific primers in nonconserved UTR regions of mouse $\beta$-tubulin genes (22). PCR screening of plasmids harboring ei-

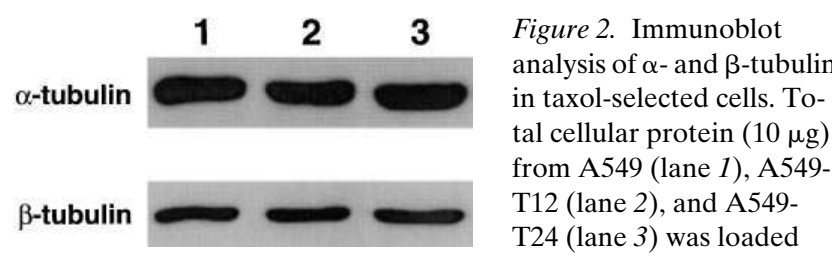

onto each lane and reacted with either $\alpha$ - or $\beta$-tubulin $\mathrm{mAb}$ and visualized using anti-mouse horseradish peroxidase-linked secondary antibody and the ECL chemiluminescence procedure. 
$\mathbf{A}$

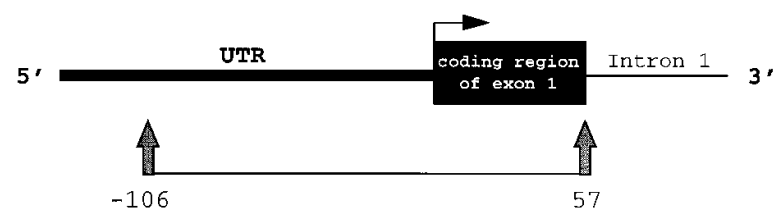

Figure 3. Partial sequence of $\beta$-tubulin gene $\mathrm{H} \beta 1$. ( $A$ ) Schematic representation of the position of the partial sequence of $\mathrm{H} \beta 1$ in relation to exon 1 . The horizontal arrow represents the ATG start site of exon 1 (nucleotides 1-57). (B) Sequence of the first 106 nucleotides in the 5'UTR and the $\mathbf{B}$ 57 nucleotides of the coding sequence of exon 1. The ATG start site is underlined and the amino acids corresponding to the nucleotide sequence of exon 1 are indicated.

ther DNA or cDNA clones of the six human $\beta$-tubulin genes demonstrated the high specificity of these isotype-specific primer pairs (Fig. $4 \mathrm{~A}$ ). In addition, 40-bp synthetic oligonucleotides were designed based on the $5^{\prime} \mathrm{UTR}$ region of HM40, $\mathrm{H} \beta 9, \mathrm{H} 5 \beta, \mathrm{H} \beta 2$, and $\mathrm{H} \beta 1$, and the $3^{\prime} \mathrm{UTR}$ region for $\mathrm{H} \beta 4$, for use in Southern and Northern analyses (Table II). The absolute specificity of these oligonucleotides was confirmed by probing Southern blots containing plasmid DNA of all six $\beta$-tubulin isotypes (Fig. $4 \mathrm{~B}$ ).

After confirmation of the specificity of the oligonucleotide primers, $\beta$-tubulin gene expression was initially determined in parental and taxol-resistant sublines. Competitive PCR involving the coamplification of a control gene, $\beta_{2}$-microglobulin,
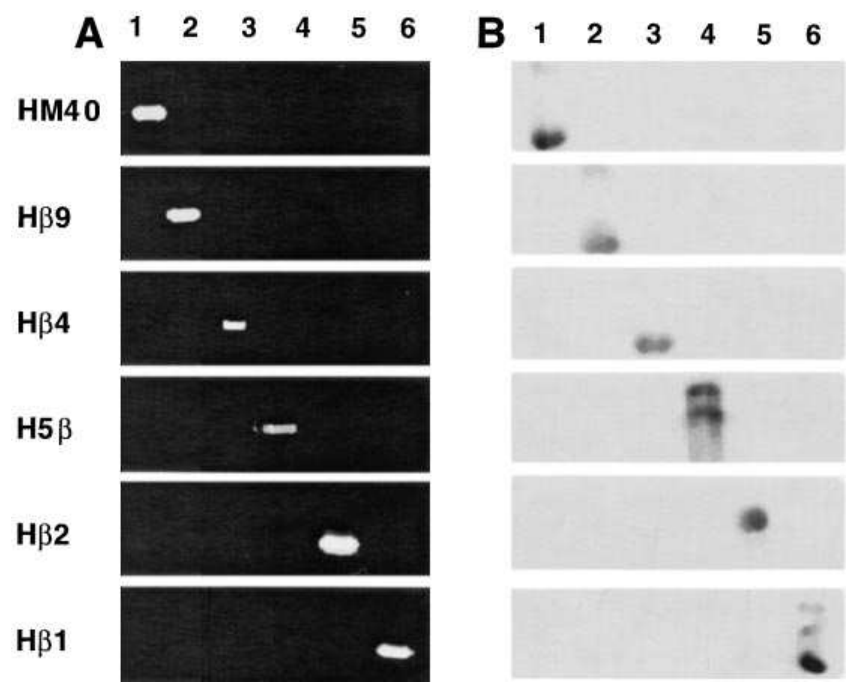

Figure 4. Specificity of $(A)$ PCR primers and $(B)$ oligonucleotide probes for the study of each of the six human $\beta$-tubulin genes. $(A)$ Plasmids harboring sequences to human $\beta$-tubulin HM40 (lane 1), $\mathrm{H} \beta 9$ (lane 2), $\mathrm{H} \beta 4$ (lane 3), H5 $\beta$ (lane 4), $\mathrm{H} \beta 2$ (lane 5), and $\mathrm{H} \beta 1$ (lane 6) genes were subjected to 35 cycles of PCR and the products $(5 \mu \mathrm{l})$ were separated by $10 \%$ PAGE before visualization by ethidium bromide staining. Gene-specific PCR primers for each reaction mix are listed in Table I. (B) Plasmid DNA (250 ng) was electrophoretically separated on $0.8 \%$ agarose gels, then alkaline-transferred to nitrocellulose membranes. Membranes were hybridized for $1 \mathrm{~h}$ with $\gamma{ }^{-32} \mathrm{P}$-labeled oligonucleotide probes at the appropriate temperature (refer to Table II), before exposure to Kodak X-Omat film. Sample loadings (lanes 1-6) are the same as those in $A$. with a specific $\beta$-tubulin isotype was used for gene expression analysis. This assay has proven useful for the semiquantitative analysis of genes in both cell lines and tumor samples $(30,32)$. Expression of $\beta$-tubulin isotypes $\mathrm{HM} 40, \mathrm{H} \beta 9$, and $\mathrm{H} \beta 4$, was found in the A549 cells and their taxol-resistant derivatives (Fig. 5). However, no product was observed for $\mathrm{H} 5 \beta, \mathrm{H} \beta 2$, and $\mathrm{H} \beta 1$ after competitive PCR. To improve the sensitivity of the assay for these three isotypes, the PCR was repeated in the absence of primers for $\beta_{2}$-microglobulin. Under these conditions, products were observed for $\mathrm{H} 5 \beta$ and $\mathrm{H} \beta 2$. The hematopoietic specific isotype, $\mathrm{H} \beta 1$, for which we obtained for the first time a partial sequence, was not expressed in either the A549, A549T12, or A549-T24 cells.

Densitometric analysis of expression levels of each of the isotypes was quantitated relative to the expression of the control gene, $\beta_{2}$-microglobulin, by determining the ratio between the target and control gene PCR products (Fig. 5). The mean PCR ratio for the most abundant isotype, HM40, was increased 1.9-fold in the most resistant cell line, A549-T24 $(P<$ $0.05)$. In contrast, $H \beta 9, H \beta 4$, and $H 5 \beta$, all expressed at low levels in A549 cells, increased approximately two- and fourfold in A549-T12 and A549-T24 cells, respectively. This increase corresponds to a concomitant increase in taxol resistance in these two sublines. Consistent with the PCR results, Northern analysis revealed an increase in expression of the $\mathrm{H} \beta 4$ gene in both A549-T12 and A549-T24 cells compared with the A549 cells (Fig. 6). Although there was an increase in $\mathrm{H} \beta 9$ gene expression, the overall levels of this gene remained relatively low as demonstrated by both the PCR ratio and the representative picture of the PCR products. Expression levels of $\mathrm{H} \beta 2$ and $\mathrm{H} \beta 1$ remained unaltered between parental and taxol-resistant cells (Fig. 5).

To determine whether an increased gene expression level of a specific tubulin isotype correlated with an increase at the protein level, A549 and A549-T24 cells were stained with an antibody to either $\alpha$-tubulin or class III $\beta$-tubulin and visualized with a fluorescent secondary antibody (Fig. 7). No change in the level of expression of $\alpha$-tubulin was seen between the two cell lines. In contrast, there is a clear increase in fluorescence intensity as determined by digital microscopy of the class III $\beta$-tubulin isotype in the A549-T24 cells compared with the drug-sensitive A549 cells. The class III $\beta$-tubulin isotype is the gene product of the $\mathrm{H} \beta 4$ gene which was found to be increased by both PCR (Fig. 5) and Northern analysis (Fig. 6) in the taxol-resistant cells. 

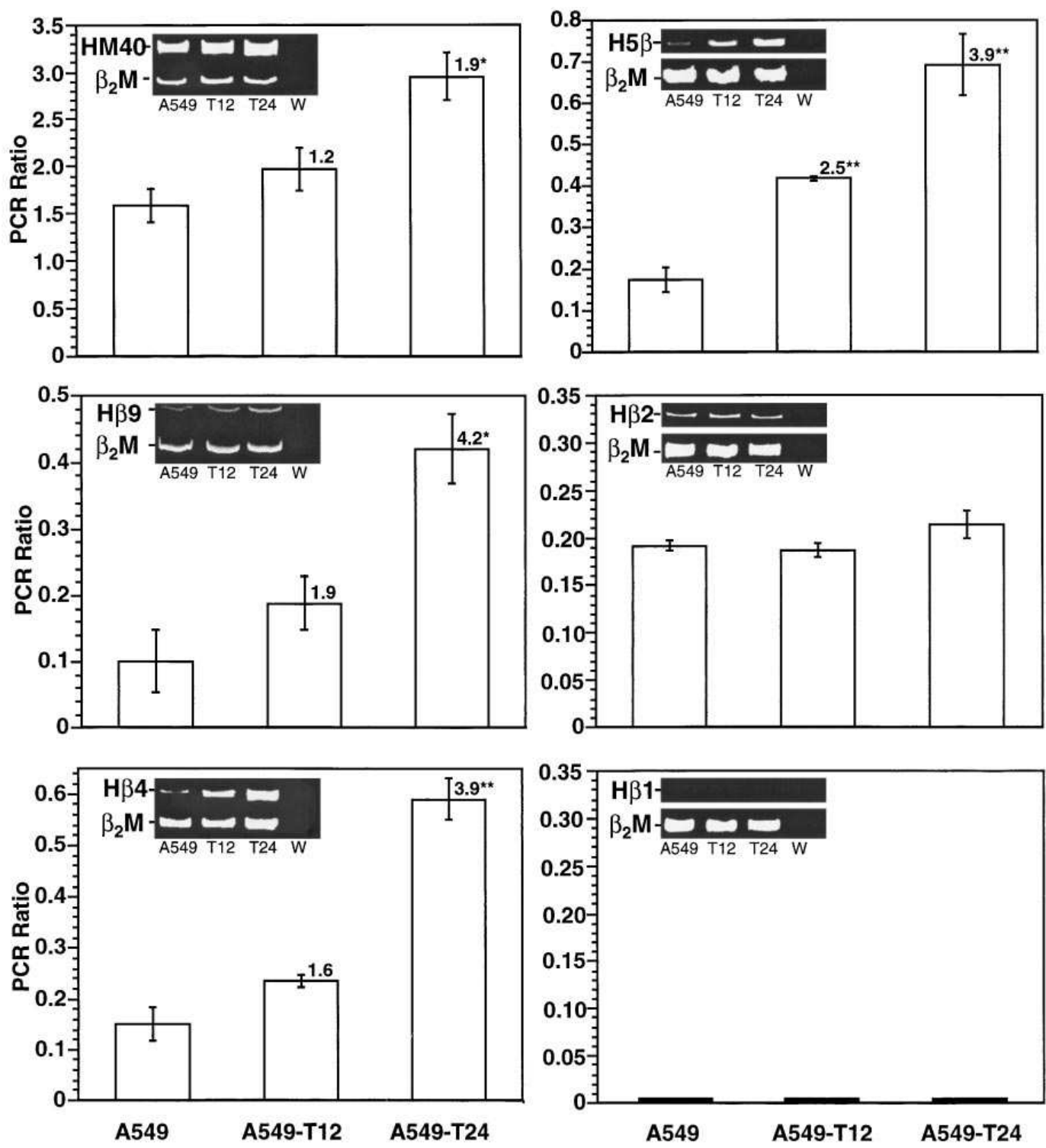

Figure 5. Expression of $\beta$-tubulin isotypes in taxol-resistant cells. RTPCR was performed in parental drug-sensitive A549 cells and in taxolresistant A549-T12 and A549-T24 cells. After competitive RT-PCR analysis of $\mathrm{HM} 40, \mathrm{H} \beta 9$, and $\mathrm{H} \beta 4$ and single primer analysis of $\mathrm{H} 5 \beta$, $\mathrm{H} \beta 2$, and $\mathrm{H} \beta 1$, ratios between the target and control $\beta_{2}$-microglobulin gene products were determined by densitometry for each sample. Between three and five independent PCR reactions were performed on each sample. Columns, mean; bars, SE; $* P<0.05$; $* * P<0.005$. Numbers at the top of the columns represent the fold increase in expression between A549 and taxolresistant cell lines. Insets are representative gels of the PCR products from A549, A549-T12, A549-T24, and a water control $(W)$.
Analysis of resistance mechanisms in primary and taxolresistant tumors. To investigate the mechanisms of clinical resistance to taxol, we examined primary and taxol-resistant ovarian and peritoneal epithelial tumors. Samples of normal ovary from pre- and postmenopausal women were included as controls. The stage, histology, and post-taxol treatment sampling times are listed in Table IV. Due to the hydrophobic nature of taxol that induces overproduction of P-glycoprotein, all tumors were initially examined for expression of the $M D R 1$ gene (Fig. 8). None of the untreated tumors expressed $M D R 1$. Of the four taxol-resistant tumors, only one, OTR3, had detectable $M D R 1$ gene expression. The level of expression was similar to that found for A549-T24 cells (Fig. 1) and was significantly lower than SKVLB cells. Unfortunately, no pretreatment tumor material was available from this patient to determine whether $M D R 1$ expression was intrinsic to the tumor or acquired after treatment. In one instance, tumor cells were available for analysis from the same patient both before (OT11) and after (OTR11) therapy. The untreated sample did not express $M D R 1$ and despite extensive chemotherapy with the
MDR-associated drugs, VP-16 and taxol, no $M D R 1$ was detected (Fig. 8).

$\beta$-Tubulin expression of each of the six isotypes was analyzed in normal ovary, untreated primary, and taxol-resistant ovarian tumors by RT-PCR. Fig. 9 depicts the mean PCR ratios of individual samples of normal ovary, primary, and taxolresistant epithelial tumor cells for $\mathrm{HM} 40, \mathrm{H} \beta 4, \mathrm{H} 5 \beta$, and $\mathrm{H} \beta 2$.

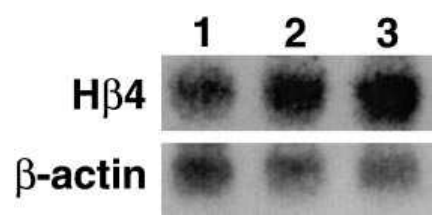

Figure 6. Northern blot analysis of $\beta$-tubulin isotype expression. Total RNA ( $30 \mu \mathrm{g} / \mathrm{lane})$ was subjected to electrophoresis in a $1 \%$ agarose gel under denaturing conditions. After transfer onto nitrocellulose

membranes, hybridization was performed as described for Fig. 4. Lane 1, A549; lane 2, A549-T12; and lane 3, A549-T24. In the top panel, hybridization was performed with a $\gamma_{-}{ }^{32} \mathrm{P}$-labeled oligonucleotide probe specific for $\mathrm{H} \beta 4$. The same membrane was reprobed with a control gene, $\beta$-actin, to confirm the loading and integrity of the RNA. 

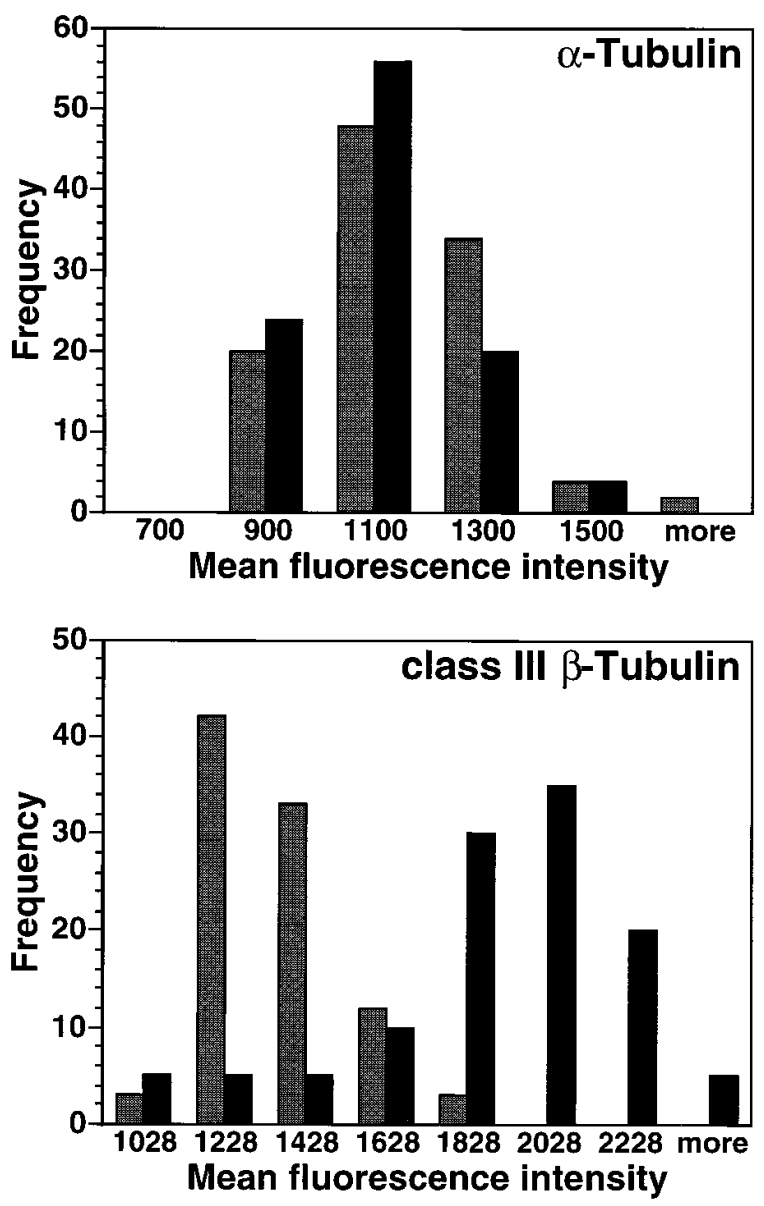

Figure 7. Immunofluorescence intensity quantitation of A549 and A549-T24 cells. Cells were probed with an mAb to either $\alpha$-tubulin (top) or class III $\beta$-tubulin (bottom). The average pixel intensity was determined for a minimum of 100 stained cells. The distribution of the intensity was determined for each cell line. Gray bars represent the A549 cells and black bars represent the A549-T24 cells. Immunofluorescence experiments were performed three times and similar results were obtained each time.

One of the untreated samples, OT11, has a matched sample, OTR11, which was clinically resistant to taxol. Significant increases in expression of HM40 $(P<0.05), \mathrm{H} \beta 4(P<0.05)$, and H5 $\beta(P<0.005)$ were observed in the taxol-resistant sample compared with the untreated sample. In contrast to the taxolresistant A549 cells described in the preceding section, levels of expression of $\mathrm{H} \beta 9$ remained low and unchanged in the human tissue samples (data not shown). Gene expression of the hematopoietic specific isotype $\mathrm{H} \beta 1$ was detected in some of the samples, but interpretation of these results was difficult due to the variable levels of blood contamination in some of the samples (data not shown).

Samples were then grouped and differences in expression of the isotypes $\mathrm{HM} 40, \mathrm{H} \beta 4, \mathrm{H} 5 \beta$, and $\mathrm{H} \beta 2$ between normal ovary, primary untreated ovarian, and taxol-resistant tumors were determined (Fig. 10). The level of gene expression for the individual $\beta$-tubulin isotypes did not differ significantly between normal ovary and primary untreated tumors. The one exception was HM40, the gene that encodes the class I isotype, which was significantly lower in primary tumors compared with normal ovary (2.6-fold decrease, $P<0.005)$. Furthermore, expression of this isotype significantly increased in resistant tumors compared with primary tumors (3.6-fold, $P<$ $0.005)$. Significant increases in gene expression were also observed for $\mathrm{H} \beta 4$ and $\mathrm{H} 5 \beta$ (4.4- and 7.6-fold, respectively, $P<$ 0.005 ) and interestingly, both of these isotypes were expressed at very low levels in normal ovaries.

Expression of the $\mathrm{H} \beta 2$ isotype was consistent between normal ovary (mean PCR ratio 0.230 ), primary (mean PCR ratio 0.187), and taxol-resistant ovarian tumor cells (mean PCR ratio 0.232 for OTR11, OTR4, and OTR5). One of the taxol-resistant samples, OTR3, expressed high levels of H 32 compared with normal ovary or primary tumors (mean PCR ratio 0.784 ). This level of expression was similar to that obtained for an ovarian carcinoma cell line, OVCAR, which was also very high compared with normal ovary (mean PCR ratio 0.778; data not shown).

\section{Discussion}

An increase in the use of taxol in the treatment of a number of human cancers and in combination with platinum as first-line therapy for advanced ovarian carcinoma, has highlighted the need to understand the mechanisms responsible for the development of resistance to this drug. Taxol resistance is most likely due to a variety of mechanisms including increased expression of the $M D R 1$ gene. Alterations in both the expression levels of the target molecule, tubulin $(7,35)$, and in the electrophoretic mobility of tubulin subunits in taxol-resistant cells have been reported (36-38). To examine the contribution of individual $\beta$-tubulin isotypes to taxol resistance, we have designed gene-specific oligonucleotides for all six human $\beta$-tubulin genes including the hematopoietic isotype, $H \beta 1$, for which we determined a partial sequence. By developing a highly specific PCR procedure we were able to examine the expression of individual $\beta$-tubulin genes in both sensitive and taxol-resistant lung cancer cell lines. Moreover, we demonstrated for the first time that clinically derived taxol-resistant ovarian epithelial tumor cells display increased expression of specific $\beta$-tubulin genes compared with primary untreated tumors.

Due to the high sequence and amino acid identity of the $\beta$-tubulin isotypes, careful selection of oligonucleotide sequences for RT-PCR was required. PCR screening of plasmids harboring the genes encoding the various isotypes established the specificity of the primer pairs. Similarly, when oligonucleotide probes were radioactively labeled and hybridized to intact plasmid DNA harboring the $\beta$-tubulin genes, no crossreactivity of the probes was observed. Therefore, these primer pairs and oligonucleotide probes provide valuable tools for the study of $\beta$-tubulin expression in human cell lines and tissues. Furthermore, the highly sensitive PCR assay is extremely useful for the analysis of gene expression where limited material is available, such as clinical samples.

Taxol-resistant human lung cancer cells, selected in the presence of low levels of taxol, did not express $M D R 1$, thereby excluding MDR as a significant mechanism of resistance. Although there was no significant change in total levels of tubulin in the resistant cell lines, this did not exclude the possibility that the relative levels of the individual $\beta$-tubulin isotypes were altered. In previous analyses of low-level taxol-resistant cell populations there also had been no increase in overall tu- 


\begin{tabular}{|c|c|c|c|c|}
\hline Sample & Stage* & Differentiation & Histology $y^{\ddagger}$ & $\begin{array}{l}\text { Tumor-bearing ascites fluid collection } \\
\text { (days after taxol treatment) }\end{array}$ \\
\hline $\mathrm{OC} 2$ & - & - & Normal premenopausal ovary & - \\
\hline $\mathrm{OC} 3$ & - & - & Normal postmenopausal ovary & - \\
\hline $\mathrm{OC} 4$ & - & - & Normal postmenopausal ovary & - \\
\hline OT3 & I & Low malignant potential & Serous & - \\
\hline OT48 & I & Low malignant potential & Mucinous & - \\
\hline OT47 & I & Well & Endometrioid & - \\
\hline OT11 & III & Poorly & Serous & - \\
\hline OT6 $6^{\S}$ & III & Poorly & Serous & - \\
\hline OT49 & IV & Poorly & Serous & - \\
\hline OT9 & IV & Poorly & Papillary serous & - \\
\hline OTR3" & III & Poorly ${ }^{\mathbb{I I}}$ & Serous & 19 \\
\hline OTR4\| & III & Moderately" & Serous & 73 \\
\hline OTR $5^{\S \|}$ & III & Poorly ${ }^{\mathbb{I}}$ & Serous & 120 \\
\hline OTR11 ${ }^{\$ \| * *}$ & III & Poorly ${ }^{\mathbb{I}}$ & Serous & 33 \\
\hline
\end{tabular}

*FIGO (International Federation of Gynecology and Obstetrics), 1988 criteria. ${ }^{*}$ Based on WHO 1973 criteria. **OTR11 is the matched drug-resistant sample of OT11, which was obtained at diagnosis. "Represents samples obtained from tumor-bearing ascites fluid. Treatment regimens for each of the patients were as follows: OTR3 (taxol/carbo, CTX/CDDP $\times 3, \mathrm{ADR} \times 2, \mathrm{HMM} \times 2$, taxol $\times 6$ ), OTR4 (taxol/CDDP $\times 4$, taxol/carbo $\times 2$, ADR/ CTX $\times 2$ ), OTR5 $($ CTX/CDDP $\times 6$, carbo/VP-16 $\times 1$, carbo $\times 2$, taxol/carbo $\times 6$ ) and OTR11 (CTX/CDDP $\times 6$, carbo/VP-16 $\times 6$, taxol $\times 5$ ). Carbo, carboplatin; $C D D P$, cisplatin; $C T X$, cytoxan; $A D R$, adriamycin; $V P-16$, etoposide; and $H M M$, hexamethylmelamine. ${ }^{\S}$ Epithelial tumors derived from peritoneum. "Differentiation status of primary tumor.

bulin expression reported $(37,39)$. There is evidence to suggest that an increase in total tubulin may not be compatible with cell viability (40, 41). However, RT-PCR analysis demonstrated increased expression of specific $\beta$-tubulin genes in these taxol-resistant cells. HM40, which encodes the class I isotype, was increased almost twofold in A549-T24. This gene is expressed to varying levels in a wide range of tissues (12) and appears to be the most abundant isotype in A549 cells. Increased expression also was observed for the gene encoding the class II isotype, $\mathrm{H} \beta 9$, which is most highly expressed in brain and to a lesser extent in lung tissue (17). Despite an approximately fourfold increase in the most resistant subline, the overall expression of this isotype remained relatively low. Previously, we reported increased expression of the murine class II isotype, $\mathrm{M} \beta 2$, in highly taxol-resistant cells (22). In addition to $\mathrm{H} \beta 9$, two brain-specific isotypes, $\mathrm{H} \beta 4$ and $\mathrm{H} 5 \beta$, which were expressed at very low levels in the parental A549 cells, increased significantly with increasing taxol resistance. Increased expression of H $\beta 4$ (class III) and H5 (class IVa) also has been reported in both taxol-selected human leukemia cells and estramustine-resistant human prostate carcinoma cells $(31,42)$.

Having demonstrated that specific $\beta$-tubulin changes are associated with taxol resistance in laboratory-derived cell lines, it was important to determine whether similar changes in expression occurred in taxol-refractory ovarian tumors. We were able to demonstrate specific $\beta$-tubulin alterations in a range of histological subtypes of both untreated epithelial and taxol-resistant ovarian tumors. Two of the $\beta$-tubulin isotype genes, $\mathrm{H} \beta 4$ and $\mathrm{H} 5 \beta$, increased significantly in the taxol-resistant tumors compared with the primary untreated tumors. Based on the following two observations, the increased expression of these two isotypes could be of importance in taxol resistance. First, increased expression of these isotypes was observed in both taxol-resistant cell lines and taxol-resistant tumors. Second, these two isotypes are brain specific and nor- mally are not expressed to significant levels in tissues of nonneuronal origin.

HM40 gene expression was significantly higher in the taxolresistant tumors (3.6-fold) than in the primary untreated tumors. Except for HM40, gene expression in normal ovary was not significantly different from that observed in primary tumors. Human ovaries are covered by a surface epithelium and $90 \%$ of all ovarian cancers are epithelial in origin (43). However, the ovary is a complex organ made up of a number of cell types, and cells of nonepithelial origin may be contributing to the increased expression of HM40 found in normal ovary. Limited information is available on the tissue and cell type distribution of $\beta$-tubulin isotypes in normal human tissues with most of the information being deduced from human cell lines (44). The other constitutively expressed $\beta$-tubulin gene, $\mathrm{H} \beta 2$, did not differ significantly between primary and taxol-resistant tumors. However, one of the resistant samples, OTR3, expressed high levels of $\mathrm{H} \beta 2$ (PCR ratio 0.628). This sample was obtained from a patient with rapid disease progression as reflected by the number of days after taxol treatment that the tumor cells were collected. Whether this increase is a reflection of the aggressiveness of the disease, or whether it reflects an

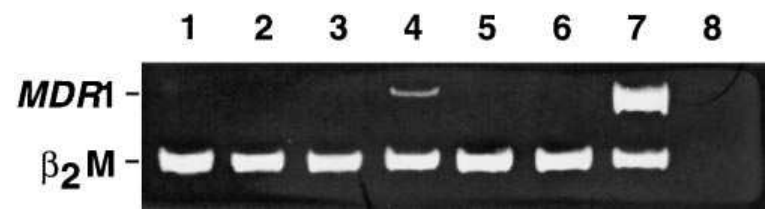

Figure 8. MDR1 expression in taxol-resistant ovarian tumors. RTPCR was performed on the following samples: OC3 (lane 1), OT11 (lane 2), OTR11 (lane 3), OTR3 (lane 4), OTR4 (lane 5), OTR5 (lane 6), SKVLB (lane 7), and water control (lane 8). Experiments were carried out as described in the legend to Fig. 1. 

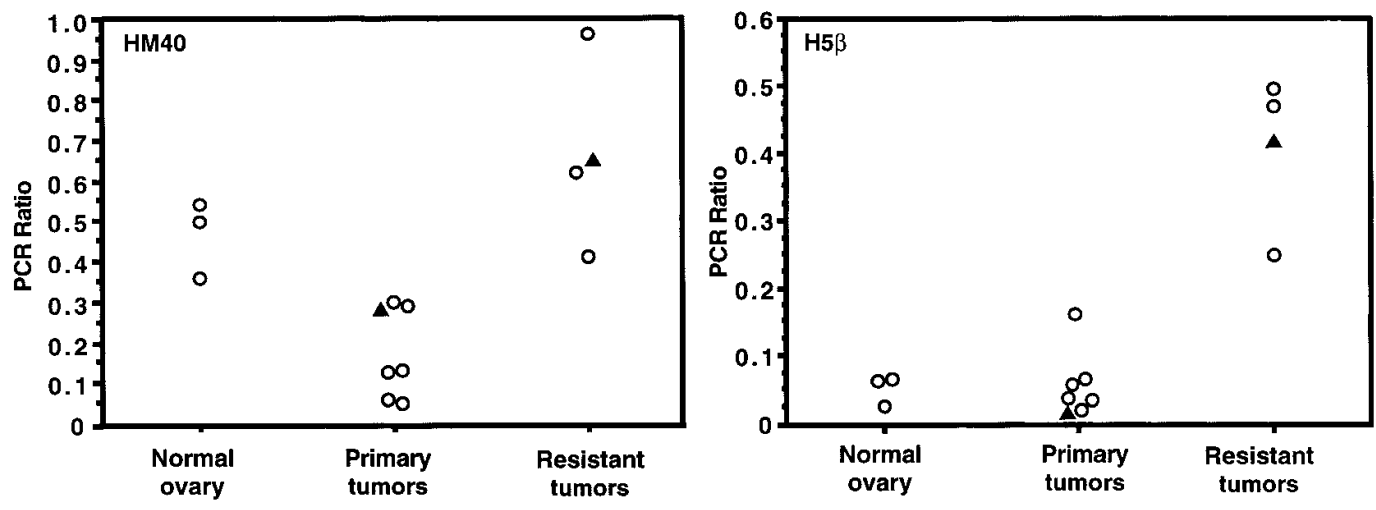

Figure 9. Distribution of gene expression levels of $\beta$-tubulin isotypes $\mathrm{HM} 40, \mathrm{H} \beta 4, \mathrm{H} 5 \beta$, and $\mathrm{H} \beta 2$ in normal ovary, primary untreated, and taxol-resistant tumors as determined by RT-PCR. Individual samples (open circles) for the four
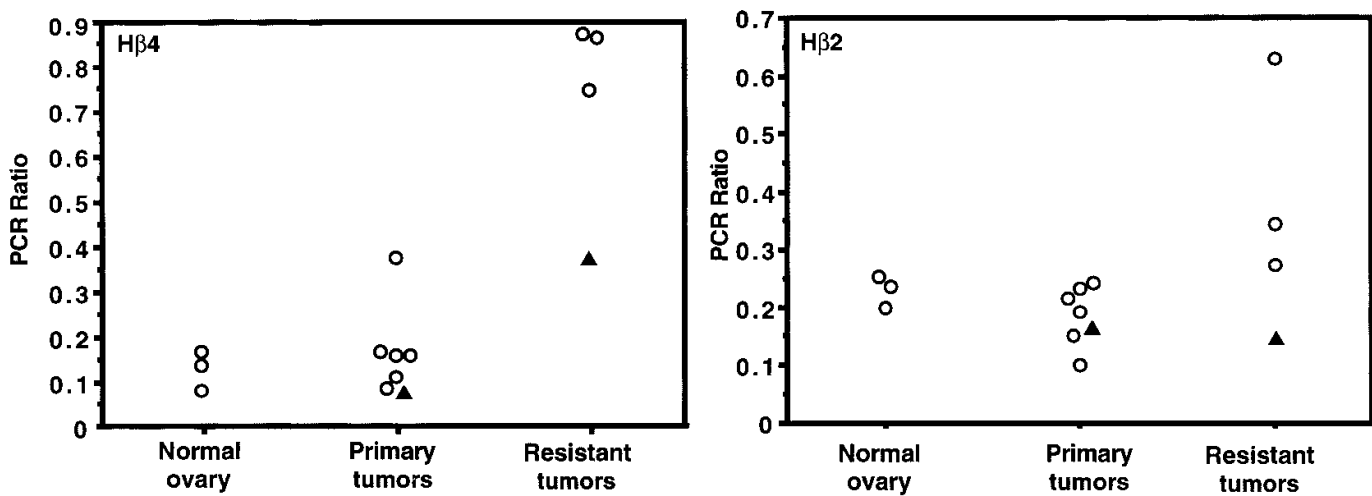

expressed isotypes represent the mean PCR ratios of three to five independent reactions. Filled triangles represent the matched sample OT11, obtained from primary untreated tumor, and tumor cells from the same patient, OTR11, obtained after taxol treatment. Experiments were carried out as described in the legend to Fig. 5.

increase as a result of the taxol treatment per se, is difficult to establish. Direct observation of changes that occur as a result of treatment can greatly contribute to our understanding of resistance mechanisms. Of the epithelial tumors analyzed in this study, one matched pair was obtained before, OT11, and after, OTR11, treatment with taxol. A very large increase (42-fold) was observed for $\mathrm{H} 5 \beta$ in the taxol-resistant sample, although accurate quantitation was difficult due to the barely detectable
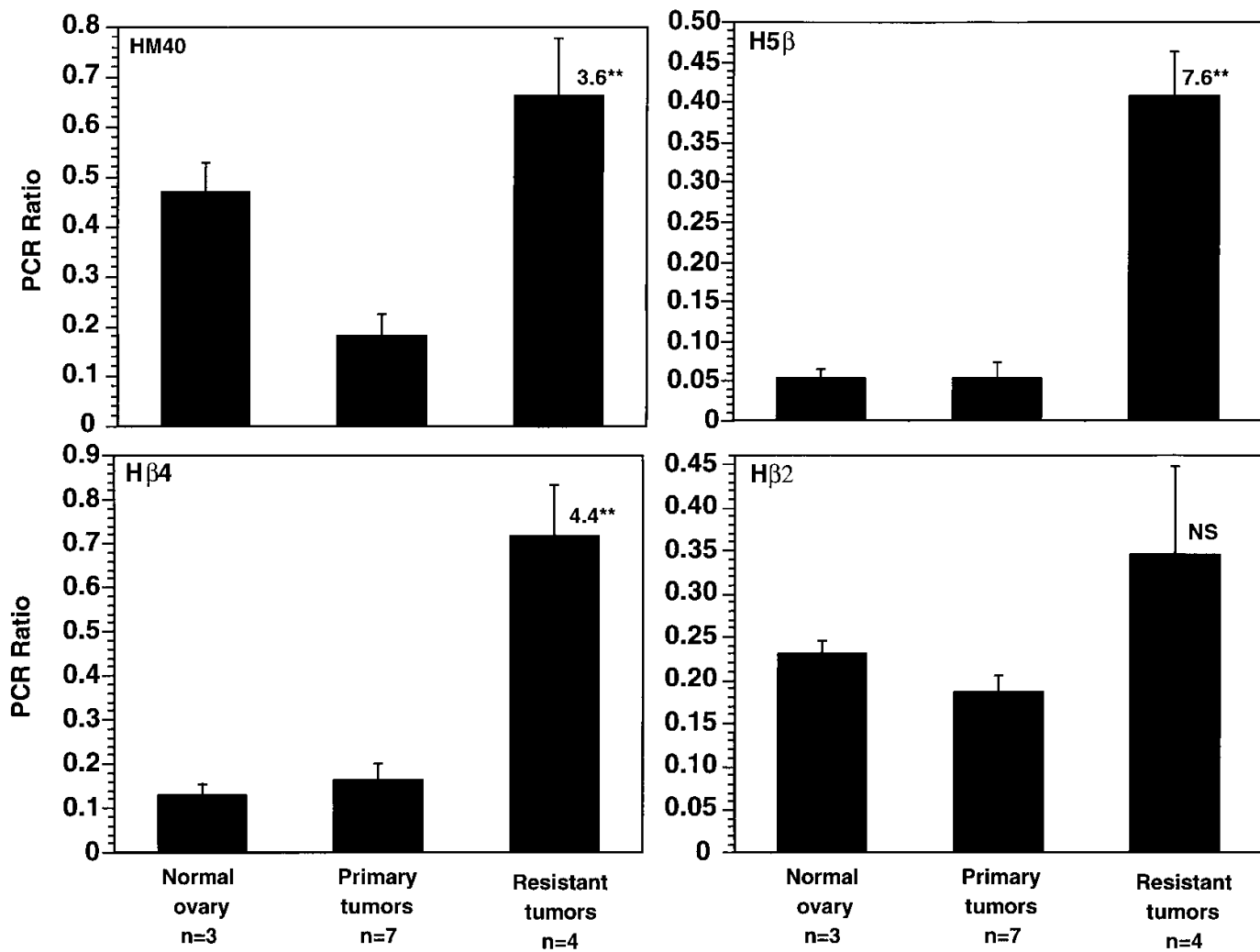

Figure 10. $\beta$-Tubulin gene expression in taxolresistant ovarian tumors. Mean PCR ratios for individual samples of normal ovary, primary untreated, and taxolresistant tumors were pooled and differences between the primary untreated and taxol-resistant tumors were determined. Columns, means; bars, SE; $* * P<0.005$.

Numbers represent the fold increase in expression between primary untreated and taxol-resistant tumors. 
levels of this gene in the untreated sample. The predominant $\beta$-tubulin isotype in platelets is H $\beta 1$ (17), and by RT-PCR high expression of this isotype was found in human platelets and to a much lesser extent in placenta (Kavallaris, M., and S.B. Horwitz, unpublished observations). This isotype shares the lowest degree of amino acid identity with the other $\beta$-tubulin isotypes and is thought to have a specialized function for the assembly of marginal bands in certain hematopoietic lineages. The cell type distribution of this isotype is thought to follow a similar pattern to that found in murine tissues, although data on the tissue-specific expression of this and other $\beta$-tubulin isotypes in human tissues and tumors are again limited (17). Although some low level $\mathrm{H} \beta 1$ gene expression was detected by noncompetitive RT-PCR for ovarian tumors, results were difficult to interpret due to low level blood contamination of some of the samples.

The increased expression of the same specific $\beta$-tubulin isotypes in both taxol-selected tumor cell lines and clinically derived taxol-resistant populations suggests that this alteration may be involved in the resistance phenotype. It had been suggested previously that the role of different tubulin isotypes may be to bind distinct microtubule-associated proteins (MAPs) and in effect add to microtubule functional variability $(17,45$, 46). Most differences among the isotypes are clustered in the carboxy-terminal region, an area involved in MAP binding (47). Posttranslational modifications of $\beta$-tubulin occur in the carboxy-terminal domain and interestingly, the four isotypes that demonstrated altered expression associated with taxol resistance, $\mathrm{HM} 40, \mathrm{H} \beta 9, \mathrm{H} \beta 4$, and $\mathrm{H} 5 \beta$, can be glutamylated (48$50)$. Glutamylation increases the acidity of an already acidic domain of the tubulin molecule and this region is functionally important due to its interaction with various MAPs. The class III $\beta$-tubulin isotype can also be phosphorylated and this posttranslational modification is thought to be involved in regulating in vivo microtubule assembly (51). While increased expression of specific $\beta$-tubulin isotypes in response to taxol treatment could be due to gene amplification in the taxol-resistant cell lines and tumors, translational and posttranslational modifications seem more likely.

Increased expression of the $M D R 1$ gene is a mechanism that has been associated with taxol resistance (7). However, untreated ovarian carcinoma generally expresses low $(29,52$, 53 ) to undetectable levels (54) of the $M D R 1$ gene. Although increased $M D R 1$ expression has been reported in some ovarian tumors treated with MDR-associated drugs (55), other factors are likely to contribute to drug resistance in this carcinoma. In our cohort of samples from both untreated and taxolresistant tumors, $M D R 1$ expression did not appear to be a significant mechanism of resistance. Only one of the taxolresistant tumors displayed $M D R 1$ gene expression and this was at a level similar to that observed for the A549-T24 cells. Furthermore, ovarian tumors which are resistant to the MDRassociated drug adriamycin are often responsive to taxol (56), indicating that mechanisms responsible for resistance in these tumors are not common to both drugs. In another gynecological malignancy, endometrial carcinoma, we have found that $M D R 1$ expression was not involved in the drug-resistance phenotype of these tumors (27). To date, cells expressing high levels of the MDR-associated protein (MRP), display either no resistance or low level resistance to taxol $(57,58)$.

Ovarian tumors used in this study were defined as taxolresistant if they had disease recurrence or progression within
6 mo of taxol-based therapy. All patients for whom tumor cells had been obtained had received multiple treatment modalities. The taxol-resistant samples had been obtained from patients that had been treated with five cycles or more of either taxol/ platinum-based combination therapy or taxol alone. All four patients had been treated with at least one other MDR-associated drug apart from taxol. However, taxol is the only drug whose cellular target is the microtubule. Although we cannot exclude the possibility that other chemotherapeutic drugs influenced the expression of specific $\beta$-tubulin isotypes, this possibility is unlikely based on available data on the mode of action and resistance mechanisms of the other drugs used in ovarian cancer therapy (59). Furthermore, clinically derived taxol-resistant ovarian tumor cells displayed similar $\beta$-tubulin alterations to the A549 cells selected solely in the presence of taxol.

Altered expression of distinct isotypes could modify tubulin/microtubule dynamics or stability of microtubules in such a way that the action of taxol is diminished. Selection of less stable isotypes could offer cells a survival advantage when exposed to a stabilizing drug such as taxol. Panda et al. (18) demonstrated that in vitro microtubule dynamics can be regulated by the tubulin isotype composition. In vitro, increased taxolinduced polymerization was observed in $\beta$-tubulin class IIIdepleted microtubules compared with nondepleted microtubules (21). Convincing evidence that alterations in $\beta$-tubulin isotype composition may modulate taxol resistance came from a recent study using purified $\beta$-tubulin isotypes (60). Microtubules composed of class III and class IV $\beta$-tubulin isotypes were found to be 7.4- and 7.2-fold less sensitive, respectively, to the effects of bound taxol than microtubules assembled from unfractionated tubulin. This strongly suggests that depending on the composition of $\beta$-tubulin isotypes, taxol can differentially modulate microtubule dynamics. Expression of both the class III ( $\mathrm{H} \beta 4$ gene product) and class IVa ( $\mathrm{H} 5 \beta$ gene product) was increased in our taxol-resistant cell lines and taxol-resistant ovarian tumors, corresponding with a reduced sensitivity of these isotypes to taxol.

With increasing use of taxol in the treatment of ovarian cancer, mechanisms responsible for resistance to this drug need to be elucidated. Drug resistance is often a multifactorial process and although we cannot exclude the possibility that mechanisms distinct from $\beta$-tubulin isotype changes are contributing to taxol resistance, we provide evidence that expression of $\beta$-tubulin isotypes $\mathrm{HM} 40, \mathrm{H} \beta 4$, and $\mathrm{H} 5 \beta$ is increased in taxol-resistant cell lines and human tumors. This strongly suggests that this alteration is contributing to the resistance phenotype. Furthermore, the mechanism by which two of the isotypes, $\mathrm{H} \beta 4$ and $\mathrm{H} 5 \beta$, which are not usually expressed in lung or ovary, are regulated in taxol-resistant cells warrants further investigation. Improved understanding of the way in which $\beta$-tubulin isotype expression is altered, and the effect it has on microtubule dynamics in response to taxol treatment in human tumors could assist in the development of strategies to circumvent resistance.

\section{Acknowledgments}

The authors thank Dr. N. Cowan and Dr. S. Lewis (New York University, NY) for providing the DNA clones for $\mathrm{HM} 40, \mathrm{H} \beta 9, \mathrm{H} 5 \beta$, $\mathrm{H} \beta 2$, and $\mathrm{H} \beta 1$, Dr. D. Cleveland (Ludwig Institute for Cancer Research, CA) for a cDNA clone of H $\beta 4$, Dr. C. Runowicz (Albert Ein- 
stein College of Medicine and Montefiore Medical Center, Bronx, New York) for her support and help in obtaining the tumor samples, and Michael Cammer and the Analytical Imaging Facility, Albert Einstein College of Medicine, for assistance with the immunofluorescence analysis.

This study was undertaken during the tenure of a Research Training Fellowship awarded by the International Agency for Research on Cancer (M. Kavallaris). C.A. Burkhart was supported by National Institute of General Medical Sciences Training Program in Pharmacological Sciences grant 5T32 GM07260. This research was supported in part by US Public Health Service grant CA39821 (S.B. Horwitz) and Cancer Core support grant CA13330.

\section{References}

1. Parker, S.L., T. Tong, S. Bolden, and P.A. Wingo. 1996. Cancer Statistics, 1996. CA Cancer J. Clin. 46:5-27.

2. Cannistra, S.A. 1993. Cancer of the ovary. N. Engl. J. Med. 329:15501559.

3. Johnson, S.W., R.E. Ozols, and T.C. Hamilton. 1993. Mechanisms of drug resistance in ovarian cancer. Cancer. 71:644-649.

4. McGuire, W.P., W.J. Hoskins, M.F. Brady, P.R. Kucera, E.E. Partridge, K.Y. Look, D.L. Clarke-Pearson, and M. Davidson. 1996. Cyclophosphamide and cisplatin compared with paclitaxel and cisplatin in patients with stage III and stage IV ovarian cancer. N. Engl. J. Med. 334:1-6.

5. Holmes, F.A., R.S. Walters, R.L. Theriault, A.D. Forman, L.K. Newton, M.N. Raber, A.U. Buzdar, D.K. Frye, and G.N. Hortobagyi. 1991. Phase II trial of taxol, an active drug in the treatment of metastatic breast cancer. J. Natl. Cancer Inst. 83:1797-1805.

6. Murphy, W.K., F.V. Fossella, R.J. Winn, D.M. Shin, H.E. Hynes, H.M. Gross, E. Davilla, J. Leimert, H. Dhingra, M.N. Raber, et al. 1993. Phase II trial of taxol in patients with untreated advanced non-small-cell lung cancer. J. Natl. Cancer Inst. 85:384-387.

7. Horwitz, S.B., D. Cohen, S. Rao, I. Ringel, H.J. Shen, and C.P. Yang. 1993. Taxol: mechanisms of action and resistance. J. Natl. Cancer Inst. Monogr. 15:55-61.

8. Wani, M.C., H.L. Taylor, M.E. Wall, P. Coggon, and A.T. McPhail. 1971. Plant antitumor agents VI. The isolation and structure of taxol, a novel antileukemic and antitumor agent from taxus brevifolia. J. Am. Chem. Soc. 93:23252327.

9. Schiff, P.B., and S.B. Horwitz. 1980. Taxol stabilizes microtubules in mouse fibroblast cells. Proc. Natl. Acad. Sci. USA. 77:1561-1565.

10. Rao, S., G.A. Orr, A.G. Chaudhary, D.G.I. Kingston, and S.B. Horwitz. 1995. Characterization of the taxol binding site on the microtubule. J. Biol. Chem. 270:20235-20238.

11. Cowan, N.J., and L. Dudley. 1983. Tubulin isotypes and the multigene tubulin families. Int. Rev. Cytol. 85:147-173.

12. Lewis, S.A., and N.J. Cowan. 1990. Tubulin genes: structure, expression, and regulation. In Microtubule Proteins. J. Avila, editor. CRC Press, Inc., Boca Raton, FL. 37-66.

13. Sullivan, K.F., and D.W. Cleveland. 1986. Identification of conserved isotype-defining variable region sequences for four vertebrate $\beta$ tubulin polypeptide classes. Proc. Natl. Acad. Sci. USA. 83:4327-4331.

14. Sullivan, K.F. 1988. Structure and utilization of tubulin isotypes. Annu. Rev. Cell Biol. 4:687-716.

15. Burgoyne, R.D., M.A. Cambray Deakin, S.A. Lewis, S. Sarkar, and N.J. Cowan. 1988. Differential distribution of $\beta$-tubulin isotypes in cerebellum. EMBO (Eur. Mol. Biol. Organ.) J. 7:2311-2319.

16. Cowan, N.J., S.A. Lewis, S. Sarkar, and W. Gu. 1987. Functional versatility of mammalian $\beta$-tubulin isotypes. In The Cytoskeleton in Cell Differentiation and Development. R. Maccioni and J. Arechaya, editors. ICSU Press, Miami, FL. 157-166.

17. Wang, D., A. Villasante, S.A. Lewis, and N.J. Cowan. 1986. The mammalian $\beta$-tubulin repertoire: hematopoietic expression of a novel heterologous $\beta$-tubulin isotype. J. Cell Biol. 103:1903-1910.

18. Panda, D., H.P. Miller, A. Banerjee, R.F. Luduena, and L. Wilson. 1994. Microtubule dynamics in vitro are regulated by the tubulin isotype composition. Proc. Natl. Acad. Sci. USA. 91:11358-11362.

19. Derry, W.B., L. Wilson, and M.A. Jordan. 1995. Substoichiometric binding of taxol suppresses microtubule dynamics. Biochemistry. 34:2203-2211.

20. Jordan, M.A., R.J. Toso, D. Thrower, and L. Wilson. 1993. Mechanism of mitotic block and inhibition of cell proliferation by taxol at low concentrations. Proc. Natl. Acad. Sci. USA. 90:9552-9556.

21. Lu, Q., and R.F. Luduena. 1993. Removal of $\beta_{\text {III }}$ isotype enhances taxol induced microtubule assembly. Cell Struct. Funct. 18:173-182.

22. Haber, M., C.A. Burkhart, D.L. Regl, J. Madafiglio, M.D. Norris, and S.B. Horwitz. 1995. Altered expression of M $\beta 2$, the class II $\beta$-tubulin isotype, in a murine J744.2 cell line with a high level of taxol resistance. J. Biol. Chem. 270:
31269-31275.

23. Roy, S.N., and S.B. Horwitz. 1985. A phosphoglycoprotein associated with taxol resistance in J774.2 cells. Cancer Res. 45:3856-3863.

24. Greenberger, L.M., L. Lothestein, S.S. Williams, and S.B.H. Horwitz. 1988. Distinct P-glycoprotein precursors are overproduced in independently isolated drug-resistant cell lines. Proc. Natl. Acad. Sci. USA. 85:3762-3766.

25. Towbin, H., T. Staehelm, and J. Gordon. 1979. Electrophoretic transfer of proteins from nitrocellulose sheets: procedure and some applications. Proc. Natl. Acad. Sci. USA. 76:4350-4354.

26. Chomczynski, P., and N. Sacchi. 1987. Single-step method of RNA isolation by acid guanidinium thiocyanate-phenol-chloroform extraction. Anal. Biochem. 162:156-159.

27. Kuo, D.Y.-S., S. Mallick, H.-J. Shen, C. DeVictoria, J. Jones, A.L. Fields, G.L. Goldberg, C.D. Runowicz, and S.B. Horwitz. 1996. Analysis of MDR1 expression in normal and malignant endometrium by reverse transcription-polymerase chain reaction and immunohistochemistry. J. Clin. Cancer Res. 2:1981-1992.

28. Chomczynski, P. 1993. TRI Reagent: RNA, DNA, Protein Isolation Reagent. Manufacturer Protocol, Molecular Research Center, Inc., Cincinnati, $\mathrm{OH}$.

29. Noonan, K.E., C. Beck, T.A. Holzmayer, J.E. Chin, J.S. Wunder, I.L. Andrulis, A.F. Gazdar, C.L. Willman, B. Grifith, D.D. Von Hof, and I.B. Roninson. 1990. Quantitative analysis of MDR1 (multidrug resistant) gene expression in human tumors by polymerase chain reaction. Proc. Natl. Acad. Sci. USA. 87:7160-7164.

30. Gilbert, J., M.D. Norris, M. Haber, M. Kavallaris, G.M. Marshall, and B.W. Stewart. 1993. Determination of N-myc gene amplification in neuroblastoma by differential polymerase chain reaction. Mol. Cell. Probes. 7:227-234.

31. Jaffrezou, J.-P., C. Dumontet, W.B. Derry, G. Duran, G. Chen, E. Tsuchiya, L. Wilson, M.A. Jordan, and B.L. Sikic. 1995. Novel mechanism of resistance to Paclitaxel (Taxol) in human K562 leukemia cells by combined selection with PSC 833. Oncol. Res. 7:517-527.

32. Bordow, S.B., M. Haber, J. Madafiglio, B. Cheung, G.M. Marshall, and M.D. Norris. 1994. Expression of the multidrug resistance-associated protein (MRP) gene correlates with amplification and overexpression of the N-myc oncogene in childhood neuroblastoma. Cancer Res. 54:5036-5040.

33. Chomczynski, P., and P.K. Qasba. 1984. Alkaline transfer of DNA to plastic membrane. Biochem. Biophys. Res. Commun. 122:340-344.

34. Khandjian, E.W., and C. Meric. 1986. A procedure for northern blot analysis of native RNA. Anal. Biochem. 159:227-232.

35. Cabral, F., and S.B. Barlow. 1989. Mechanisms by which mammalian cells acquire resistance to drugs that affect microtubule assembly. FASEB (Fed. Am. Soc. Exp. Biol.) J. 3:1593-1599.

36. Cabral, F.R., R.C. Brady, and M.J. Schibler. 1986. A mechanism of cellular resistance to drugs that interfere with microtubule assembly. Ann. NY Acad. Sci. 466:745-756.

37. Ohta, S., K. Nishio, N. Kubota, T. Ohmori, Y. Funayama, T. Ohira, H. Nakajima, M. Adachi, and N. Saijo. 1994. Characterisation of a taxol-resistant human small-cell lung cancer cell line. Jpn. J. Cancer Res. 85:290-297.

38. Laferriere, N.B., and D.L. Brown. 1995. Effects of taxol on the polymerization and posttranslational modification of class III $\beta$-tubulin in P19 embryonal carcinoma cells. Biochem. Cell Biol. 73:687-694.

39. Minotti, A.M., S.B. Barlow, and F. Cabral. 1991. Resistance to antimitotic drugs in Chinese hamster ovary cells correlates with changes in the level of polymerized tubulin. J. Biol. Chem. 266:3987-3994.

40. Weinstein, B., and F. Solomon. 1990. Phenotypic consequences of tubulin overproduction in Saccharomyces cerevisiae: differences between alphatubulin and beta-tubulin. Mol. Cell. Biol. 10:5295-5304.

41. Burke, D., P. Gasdaska, and L. Hartwell. 1989. Dominant effects of tubulin overexpression in Saccharomyces cerevisiae. Mol. Cell. Biol. 9:1049-1059.

42. Ranganathan, S., D.W. Dexter, C.A. Benetatos, A.E. Chapman, K.D Tew, and G.R. Hudes. 1996. Increase of $\beta_{\mathrm{IU}^{-}}$and $\beta_{\mathrm{IV}}$-tubulin in human prostate carcinoma cells as a result of estramustine resistance. Cancer Res. 56:2584-2589.

43. Murdoch, W.J. 1996. Ovarian surface epithelium, ovulation and carcinogenesis. Biol. Rev. 71:529-543.

44. Lewis, S.A., M.E. Gilmartin, J.L. Hall, and N.J. Cowan. 1985. Three expressed sequences within the human $\beta$-tubulin multigene family each define a distinct isotype. J. Mol. Biol. 182:11-20.

45. Lewis, S.A., W. Gu, and N.J. Cowan. 1987. Free intermingling of mammalian $\beta$-tubulin isotypes among functionally distinct microtubules. Cell. 49 : $539-548$.

46. Lewis, S.A., M. Gwo-Shu Lee, and N.J. Cowan. 1985. Five mouse tubulin isotypes and their regulated expression during development. J. Cell Biol. 101:852-861.

47. Luduena, R.F. 1993. Are tubulin isotypes functionally significant? Mol. Biol. Cell. 4:445-457.

48. Alexander, J.E., D.F. Hunt, M.K. Lee, J. Shabanowitz, H. Michel, S.C. Berlin, T.L. Macdonald, R.J. Sunberg, L.I. Rebhun, and A. Frankfurter. 1991 Characterization of posttranslational modifications in neuron-specific class III ß-tubulin by mass spectrometry. Proc. Natl. Acad. Sci. USA. 88:4685-4689.

49. Mary, J., V. Redeker, J.-P. Le Caer, J.-G. Prome, and J. Rossier. 1994. Class I and IVa $\beta$-tubulin isotypes expressed in adult mouse brain are glutamy- 
lated. FEBS (Fed. Eur. Biochem. Soc.) Lett. 353:89-94.

50. Rudiger, M., U. Plessman, K.-D. Kloppel, J. Wehland, and K. Weber. 1992. Class II tubulin, the major brain $\beta$ tubulin isotype is polyglutamylated on glutamic acid residue 435. FEBS (Fed. Eur. Biochem. Soc.) Lett. 308:101-105.

51. Khan, I.A., and R.F. Luduena. 1996. Phosphorylation of $\beta_{\mathrm{III}}$-tubulin. Biochemistry. 35:3704-3711.

52. Holzmayer, T.A., S. Hilsenbeck, D.D. Don Hoff, and I.B. Roninson. 1992. Clinical correlates of MDR1 (P-glycoprotein) gene expression in ovarian and small-cell lung carcinomas. J. Natl. Cancer Inst. 84:1486-1491.

53. Kavallaris, M., J.A. Leary, J.A. Barrett, and M.L. Friedlander. 1996. MDR1 and multidrug resistance-associated protein (MRP) gene expression in epithelial ovarian tumors. Cancer Lett. 102:7-16.

54. Bourhis, J., L.J. Goldstein, G. Riou, I. Pastan, M.M. Gottesman, and J. Benard. 1989. Expression of a human multidrug resistance gene in ovarian carcinomas. Cancer Res. 49:5062-5065.

55. Bell, D.R., J.H. Gerlach, N. Kartner, R.N. Buick, and V. Ling. 1985. Detection of P-glycoprotein in ovarian cancer: a molecular marker associated with multidrug resistance. J. Clin. Oncol. 3:311-315.

56. McGuire, W.P., E.K. Rowinsky, N.B. Rosenshein, F.C. Grumbine, D.S.
Ettinger, D.K. Armstrong, and R.C. Donehower. 1989. Taxol: a unique antineoplastic agent with significant activity in advanced ovarian epithelial neoplasms. Ann. Intern. Med. 111:273-279.

57. Zaman, G.J.R., M.J. Flens, M.R. van Leusden, M. de Haas, H.S. Mulder, J. Lankelma, H.M. Pinedo, R.J. Scheper, F. Baas, H.J. Broxterman, and P. Borst. 1994. The human multidrug-resistance-associated protein MRP is a plasma membrane drug-efflux pump. Proc. Natl. Acad. Sci. USA. 91:8822-8826.

58. Cole, S.P.C., K.E. Sparkes, K. Fraser, D.W. Loe, C.E. Grant, G.M. Wilson, and R.G. Deeley. 1994. Pharmacological characterisation of multidrug resistant MRP-transfected human tumor cells. Cancer Res. 54:5902-5910.

59. Van Der Zee, A.G.J., H.H. Hollema, H.W.A. De Bruijn, P.H.B. Willemse, H. Boonstra, N.H. Mulder, J.G. Aalders, and E.G.E. De Vries. 1995 Cell biological markers of drug resistance in ovarian carcinoma. Gynecol. Oncol. 58:165-178.

60. Derry, W.B., S. Wilson, I.A. Khan, R.F. Luduena, and M.A. Jordan. 1997. Taxol differentially modulates the dynamics of microtubules assembled from unfractionated and purified $\beta$-tubulin isotypes. Biochemistry. 36:35543562 . 